\title{
The Image of Politics in Art: Projecting the Oppression in Turkish Art Scene
}

\author{
Ayşe Nahide Yilmaz \\ Dr., Duzce University Art, Design and Architecture Faculty
}

\begin{abstract}
In the 1970s, Turkey's artistic milieu was mostly influenced by socialist realistic painters who demonstrated political criticism with a figurative understanding. The oppression that came with the coup d'etat of September 12, 1980 aimed at a depoliticized society, and artists were then politically diverted to implicit and indirect ways. While direct intervention from the military or the civil government under its control rarely came, the artists and art institutions have even ended some kind of auto censorship. In a demoralized and depoliticized cultural environment, the works that embodied the 'social ghost' have both raised emotional and reactive objections and ironically created a sense of guilt in the audience. Being a spectator meant to be a victim, a judge, a witness, or maybe -in fact- all of these at once. The artist imagination reproducing the notions of authority and power in silenced societies has made conspicuous human rights violations, tortures, and executions through works of art. Artists, who counted art as a vehicle to change the world, have provided a deep dimension in art environment with a wide variety of knowledge and skills right along with new techniques and materials. In this work, there shall be many examples of artists and works of art that combine 'art politics' and 'political art' as a single thing, which goes beyond traditional approaches to art and politics in the intense and subversive political atmosphere of the 1980s in Turkey.
\end{abstract}

Keywords: Coup d'état, $12^{\text {th }}$ September 1980 , Republic of Turkey, work of art, politics, artist, torture 